Historic, Archive Document

Do not assume content reflects current scientific knowledge, policies, or practices. 



\section{Ponderosa Pine Mortality Resulting from a Mountain Pine Beetle Outbreak}

William F. McCambridge, Frank G. Hawksworth, Carleton B. Edminster and John G. Laut

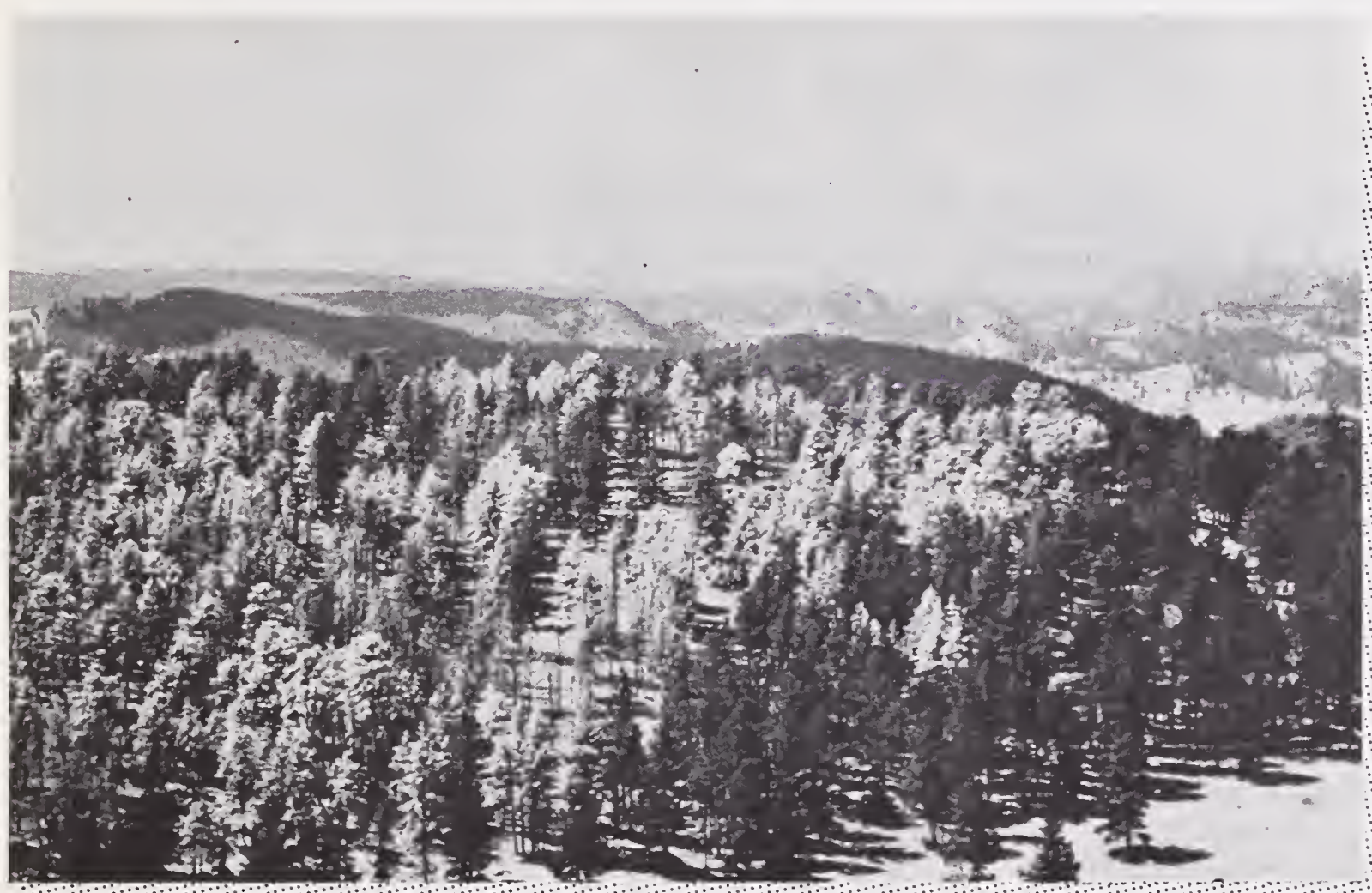




\title{
Ponderosa Pine Mortality Resulting from a Mountain Pine Beetle Outbreak
}

\author{
William F. McCambridge, Entomologist \\ Frank G. Hawksworth, Forest Pathologist \\ Carleton B. Edminster, Mensurationist \\ Rocky Mountain Forest and Range Experiment Station \\ USDA Forest Service ${ }^{1}$
}

\author{
John G. Laut, Senior Staff Forester \\ Insect and Disease Division \\ Colorado State Forest Service ${ }^{2}$
}

\begin{abstract}
From 1965 to 1978 , mountain pine beetles killed $25 \%$ of the pines taller than 4.5 feet in a study area in north-central Colorado. Average basal area was reduced from 92 to 58 square feet per acre. Mortality increased with tree diameter up to about 9 inches d.b.h. Larger trees appeared to be killed at random. Mortality was directly related to number of trees per acre and presence of dwarf mistletoe, but not to site index, elevation, or percent Douglas-fir in the stand.
\end{abstract}




\title{
Ponderosa Pine Mortality Resulting from a Mountain Pine Beetle Outbreak
}

\author{
William F. McCambridge, Frank G. Hawksworth, Carleton B. Edminster, \\ and John G. Laut
}

\section{Management Implications}

Mountain pine beetles (Dendroctonus ponderosae Hopkins) in outbreak numbers do not kill whole forests. Many ponderosa pine (Pinus ponderosa var. scopulorum Engelm.) trees of all diameters, as well as relatively intact patches and stands of trees, survive. A few scattered stands will be almost completely killed. If overstocked stands of relatively large tree diameters are allowed to develop over widespread areas, control programs aimed only at treating infested trees are unsound. Trees must also be thinned to some acceptable stocking level.

Silvicultural manipulation to favor nonhost trees, such as Douglas-fir (Pseudotsuga menziesii var. glauca (Beissn.) Franco) over ponderosa pine in order to "bug proof" stands, seems of little benefit in an outbreak unless one is willing to convert most of the stand to nonhost trees.

Dwarf-mistletoe-infected (Arceuthobium vaginatum subsp. cryptopodum (Engelm.) Hawksw. and Wiens) ponderosa pines are more susceptible to mountain pine beetle attacks than are healthy trees. Consequently, forest management practices aimed at reducing stand risk to bark beetles by thinning stands should simultaneously remove dwarf-mistletoe-infected trees.

\section{Introduction}

This paper provides some answers to the question "What happens to a ponderosa pine forest during an uncontrolled mountain pine beetle outbreak?" The objective of the paper is to present specific data on the amount of beetle-caused tree and stand mortality. Tree mortality is considered in relation to tree diameter, stand density, elevation, site index, aspect, Douglas-fir component, and dwarf mistletoe infection.

\section{History of the Outbreak}

Mountain pine beetles began infesting small groups of ponderosa pine in Lory State Park near Fort Collins, Colo., about 1965. Beetles infested approximately 300 trees throughout 1,220 forested acres of the park in
1967 , and the rate increased to about 1,000 per year by 1968. By the end of 1973, numerous groups of 25-50 actively infested pines were distributed throughout the forest. Several thousand trees are believed to have been killed by 1973 .

Maximum tree mortality occurred during 1974, 1975 , and 1976 and was estimated at about 20,000 trees per year. Infested trees were noticeably fewer in 1977. The outbreak ended in 1978, when only a few, scattered trees were lightly infested.

The mountain pine beetle epidemic in the park was part of a large outbreak that extended about 180 miles from the Wyoming-Colorado border, southward to the vicinity of Canon City, Colo., and encompassed about $2,000,000$ acres of ponderosa pine type.

\section{The Study Area}

Lory State Park is 7 miles west of Fort Collins, Colo. The elevation of the forest within the park extends from 5,840 to 7,015 feet. While ponderosa pine is the principal type, individual Douglas-firs are scattered in the pine stands and grow in pure stands on northfacing slopes. Pine stands on steep, south slopes consist of scattered, open grown trees.

Annual precipitation, extrapolated from Redfeather Lakes, Estes Park, and Fort Collins, is approximately 20 inches. Most of this falls as late winter and early spring snows and as summer showers.

The mean age of 509 dominant or codominant ponderosa pines was $101 \pm 3$ years. Pine stands in the park are generally uneven-aged, consisting of an irregular mosaic of small, even-aged patches of trees established following homestead clearings, mining, fires, and barkbeetle epidemics.

\section{Methods}

Crews conducted the survey of mountain-pine-beetlecaused damage throughout the forested area of Lory State Park in October 1978. Crews sampled 189 BAF 5 variable-radius plots, 179 of which were forested. Plot centers were on an 8-chain square grid pattern. Grid lines were closed (distance and direction to previous line measured) at each end, so actual plot locations could be determined. The elevation of each plot was then estimated from a U.S. Geological Survey contour map of the area. 
At each forested plot, crews determined the aspect and recorded the following data for each tree taller than 4.5 feet: tree species, d.b.h. to the nearest $0.1 \mathrm{inch}$; life status (i.e., alive, beetle-killed, or dead from unknown causes); and the dwarf mistletoe rating (Hawksworth 1977) for live ponderosa pines, or a notation of evidence of dwarf mistletoe if the tree was dead. The height to nearest foot of two trees in each 1-inch diameter class, and the age of three dominant or codominant trees at 1 foot above mean ground line, were also determined.

The average length of time required for ponderosa pines to reach a height of 1 foot was determined by felling 112 saplings and counting annual rings at ground level and at 1 foot. The mean number of years to grow the first foot, $7 \pm 1$, was added to the mean age of cores taken at 1 foot for determining site index from curves using total age (Meyer 1938).

The least sampling unit used in analyzing the data was the BAF 5 variable-radius plot. Calculations of analyses of variance, Pearson coefficients of correlation, $t$ tests, and multiple regressions were made as needed.

Within the forest at Lory State Park is an irregular shaped area of 163 contiguous acres of ponderosa pine which suffered heavy tree mortality from beetle attacks. This area has an elevation range of 6,720-6,960 feet. Tree mortality within the area was compared to that for the whole forest and to other plots at similar elevations where overall tree mortality was less to ascertain the tree or stand characteristics associated with very heavy beetle-caused tree mortality.

\section{Results and Discussion: Factors Affecting Beetle-caused Tree Mortality}

Mountain pine beetles killed an average of 92 ponderosa pines per acre in Lory State Park. This was $25 \%$ of the original live pines, containing $37 \%$ of the pine basal area and $44 \%$ of the merchantable board foot volume. During the outbreak, beetles killed approximately 112,500 ponderosa pines, containing a merchantable volume of 1.2 million board feet worth about $\$ 17,000 .^{3}$ Lory State Park is managed for recreation and wildlife habitat; consequently, the major direct cost of the beetle outbreak may be the money spent in the future to remove dead trees adjacent to hiking trails for safety and area accessibility.

Within the 163 contiguous acres of very heavy beetle-caused mortality, 273 trees $(49 \%$ of the pine stems) were killed per acre. These pines contained $84 \%$ of the original pine basal area and represent a loss of more than 3,000 board feet per acre-99\% of the original merchantable board foot volume.

\section{Tree Diameter}

The average d.b.h. (average d.b.h. is the diameter of the tree of average basal area) of all live ponderosa pine 4.5 feet tall and taller was reduced from 8.9 inches to 8.3 inches during the outbreak (table 1). Tree mortality by diameter class is shown in table 2 . Mountain pine beetles killed trees down to the 1-inch

${ }^{3}$ Average stumpage value between 1974 and 1977 equaled $\$ 14.30$ per thousand board feet. Data from Proof Listing of Timber Sale Report, USDA Forest Service, Rocky Mountain Region, Denver, Colo.

Table 1.-Comparison of characteristics of ponderosa pine forest study areas having heavy beetle-caused mortality or moderate mortality versus whole-forest characteristics'

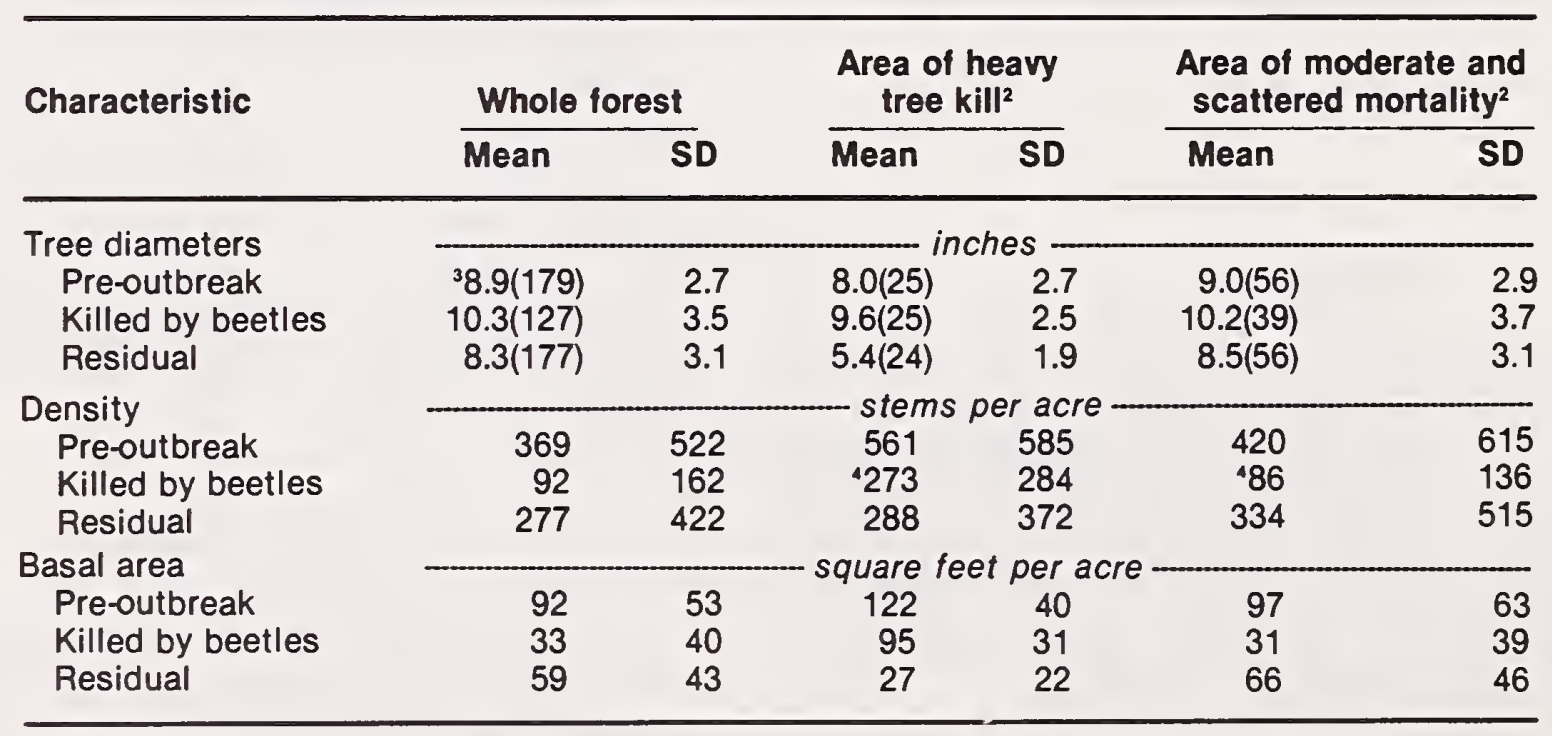

'Analysis includes trees 4.5 feet and taller.

${ }^{2}$ Altitudes of study areas are similar (6,720 to 6,960 feet); analysis includes trees 4.5 feet and taller.

${ }^{3}$ Number of plots used is given in parentheses after the mean value. Sample size for whole area was 179 forested plots; for area of heavy kill, 25; and for area of moderate tree kill, 56 plots. Where sample sizes in a given column are unequal, some plots did not contain characteristic measured. For example, 2 plots taken from the whole forest contained no residual trees, while 52 plots had no trees killed by beetles.

"Difference significant at $\mathrm{P}<0.001$. 
Table 2.-Overall tree mortality (by diameter class) caused by mountain pine beetle, sample plots, Lory State Park, Colo., 1978

\begin{tabular}{|c|c|c|c|c|}
\hline \multirow{2}{*}{$\begin{array}{l}\text { Diameter } \\
\text { class } \\
\text { (midpoint) }\end{array}$} & \multicolumn{2}{|c|}{$\begin{array}{l}\text { Total trees } \\
(n=3474)\end{array}$} & \multicolumn{2}{|c|}{$\begin{array}{l}\text { Trees killed } \\
(n=1239)\end{array}$} \\
\hline & number & $\begin{array}{c}\text { percent } \\
\text { (of all trees) }\end{array}$ & number & percent \\
\hline${ }_{1}$ & 14 & $<1$ & 0 & 0 \\
\hline 3 & 197 & 6 & 17 & 9 \\
\hline 5 & 389 & 11 & 73 & 19 \\
\hline 7 & 537 & 15 & 196 & 36 \\
\hline 9 & 610 & 17 & 265 & 43 \\
\hline 11 & 561 & 16 & 236 & 42 \\
\hline 13 & 506 & 15 & 220 & 43 \\
\hline 15 & 344 & 9 & 142 & 41 \\
\hline 17 & 167 & 4 & 51 & 30 \\
\hline 19 & 87 & 2 & 21 & 24 \\
\hline 21 & 34 & 1 & 11 & 33 \\
\hline 23 & 15 & $<1$ & 1 & 6 \\
\hline 25 & 3 & $<1$ & 2 & 66 \\
\hline 27 & 3 & $<1$ & 0 & 0 \\
\hline 29 & 3 & $<1$ & 2 & 66 \\
\hline 31 & 1 & $<1$ & 1 & 100 \\
\hline 33 & 2 & $<1$ & 0 & 0 \\
\hline 35 & 1 & $<1$ & 1 & 100 \\
\hline
\end{tabular}

10-1.9, etc.

diameter class. Percent of trees killed in each diameter class increased steadily up to 9 inches. The lack of a sharp demarcation in number of attacks at some smaller diameter implies that, during outbreaks, no specific minimum tree diameter exists below which trees are immune from beetle attack.

Approximately equal percentages of pines between 8 and 14 inches d.b.h. were killed. Beetle-caused tree mortality appears to lessen or become erratic for trees larger than 14 inches d.b.h. This relationship may actually exist, although the correlation coefficient for percent of trees killed versus d.b.h. $(-0.04)$ indicates no relationship. For the largest diameters, the sample sizes are too small for inference. In any event, some large trees survived this outbreak.

The distribution of pine diameters within Lory State Park reveals a lack of small trees. For example, trees smaller than 4 inches d.b.h., but at least 4.5 feet tall, account for only $6 \%$ of the stems. On the other hand, trees from 4 to 14 inches d.b.h. account for almost $81 \%$ of the stems.

In the 163-acre area of high beetle-caused tree mortality, average d.b.h. of pines decreased significantly from 8.0 inches prior to the outbreak to 5.4 inches at its end. Prior to the outbreak, the average d.b.h. of pines in this area was 0.9 inch smaller (table 1) than the mean for pines in the whole forested area, but the difference was not significant. Average d.b.h. of 8.0 inches in the area of heavy tree mortality was not statistically different from 9.0 inches for plots at the same elevational range where tree kill was much less severe.

The percent of trees killed by beetles in the area of high tree mortality, for the most part, increased as tree diameter increased up to 12 inches (table 3). There was a drop in percent tree mortality in the 14- and 15-inch diameter classes, probably caused by chance.

A more erratic pattern of tree mortality relative to diameter is seen in table 4. This area of moderate beetle-caused damage within the same elevational range as the 163-acre area more closely resembles in tree and stand characteristics the area as a whole (table 1). The pattern of tree mortality increasing as diameter increased reveals a somewhat haphazard selection by the beetles.

The relationship between ponderosa pine tree diameter and mortality resulting from mountain pine beetle attacks at Lory State Park can be summed up as follows: (1) Tree mortality over the area did not correlate well with diameter. When this outbreak had run its course, many large trees had survived. (2) The percent of trees killed by beetles increased as diameters increased, but not indefinitely. Trees 8 or 9 inches in diameter were almost as likely to be killed as larger trees. (3) No specific d.b.h. exists below which trees escaped mountain pine beetle attacks. (4) However, the steep downturn in percent of trees killed appears to lie in the vicinity of 8-9 inches d.b.h. This is similar to data from lodgepole pine provided by Cole and Amman (1969). This diameter range may be useful for establishing a minimum diameter in managed even-aged stands where mountain pine beetles are a problem. (5) Heaviest stand destruction did not occur where mean tree diameter was greatest.

\section{Stand Density}

Stand density for trees 4.5 feet and taller can be expressed as trees per acre or basal area per acre. Of the two, original trees per acre appears to give the stronger correlation with the number of trees killed by the beetles $(r=0.71$ versus 0.61). A multiple regression

Table 3. - Tree mortality (by diameter class) in heavy loss area, sample plots, Lory State Park, Colo., 1978

\begin{tabular}{lcc}
\hline $\begin{array}{l}\text { Diameter } \\
\text { class }\end{array}$ & Total trees & Trees killed \\
(midpoint) & $(n=615)$ & $(n=471)$
\end{tabular}

\begin{tabular}{rrrrr}
\hline inches & number & $\begin{array}{c}\text { percent } \\
\text { (of all trees) }\end{array}$ & number & percent \\
11 & 5 & $<1$ & 0 & 0 \\
3 & 31 & 5 & 2 & 6 \\
5 & 73 & 12 & 28 & 38 \\
7 & 103 & 17 & 71 & 69 \\
9 & 124 & 20 & 111 & 90 \\
11 & 111 & 18 & 100 & 90 \\
13 & 101 & 16 & 99 & 99 \\
15 & 50 & 8 & 44 & 88 \\
17 & 14 & 2 & 13 & 93 \\
19 & 3 & $<1$ & 3 & 100 \\
& & & & \\
\hline
\end{tabular}

10-1.9, etc. 
analysis showed that this relationship of tree mortality was not strengthened when compared to the combined interaction of original trees per acre $\times$ original basal area $(r=0.68)$, or the interaction of original trees with d.b.h. $(r=0.71)$.

Ponderosa pine were significantly reduced from 369 to 277 trees per acre within the park $(P<0.001)$. In the area of heavy beetle-caused tree mortality, the density of pine stems, 561 per acre, was not statistically different from that for the area as a whole, 369 per acre, or for the area of moderate tree mortality at similar elevations, 420 per acre (table 1). The large standard deviations accompanying these means indicates a need for additional sampling before we could say whether the beetles did or did not prefer the more dense stand.

The basal area of ponderosa pine at Lory State Park was reduced from 92 to 58 square feet per acre (table 1). This difference is significant at $P<0.001$. The large variations in basal area between sample plots is evident in the large standard deviations. In the area of heavy tree mortality, the basal area of pine was significantly greater than that for the entire forested area (122 versus 92 square feet per acre, $P<0.001$ ), but it was not different $(P=0.05)$ from mean basal area in the areas at similar elevation containing less tree kill (97 square feet per acre).

The loss of $25 \%$ of pine stems when the accompanying basal area was 92 square feet suggests that present cutting guides calling for a residual stand of 80 basal feet may not reduce the susceptibility of stands sufficiently during outbreaks. Tree spacing and residual diameter may be additional stand characteristics worthy of consideration.

Table 4.- Tree mortality (by diameter class) in moderate loss area, sample plots, Lory State Park, Colo., 1978

\begin{tabular}{llc}
\hline $\begin{array}{l}\text { Diameter } \\
\text { class } \\
\text { (midpoint) }\end{array}$ & $\begin{array}{l}\text { Total trees } \\
(n=1166)\end{array}$ & $\begin{array}{c}\text { Trees killed } \\
(n=364)\end{array}$ \\
\hline
\end{tabular}

\begin{tabular}{crcrc}
\hline inches & number & $\begin{array}{c}\text { percent } \\
\text { (of all trees) }\end{array}$ & number & percent \\
-1 & 5 & $<1$ & 0 & 0 \\
3 & 74 & 6 & 7 & 10 \\
5 & 153 & 13 & 27 & 18 \\
7 & 192 & 16 & 56 & 29 \\
9 & 201 & 17 & 68 & 34 \\
11 & 175 & 15 & 74 & 42 \\
13 & 167 & 14 & 61 & 37 \\
15 & 109 & 9 & 43 & 39 \\
17 & 41 & 4 & 9 & 22 \\
19 & 19 & 2 & 7 & 37 \\
21 & 10 & $<1$ & 5 & 50 \\
23 & 9 & $<1$ & 1 & 11 \\
25 & 2 & $<1$ & 2 & 50 \\
27 & 4 & $<1$ & 1 & 25 \\
29 & 3 & $<1$ & 2 & 66 \\
31 & 1 & $<1$ & 1 & 100 \\
33 & 0 & $<1$ & 0 & 0 \\
35 & 1 & $<1$ & 1 & 100 \\
& & & & \\
\hline
\end{tabular}

'0-1.9, etc.

\section{Elevation}

Elevation was not significantly correlated with percent of pine trees killed by beetles $(r=0.23)$; with site index $(r=0.01)$; with ponderosa pine stems per acre $(\mathrm{r}=0.19)$; with pine basal area $(\mathrm{r}=0.23)$; or with Douglas-fir per acre $(r=-0.03)$.

\section{Site Index and Aspect}

The range of ponderosa pine site indexes was 25-82 feet, with a mean of $47.2 \pm 1.94$ feet. Site index had no significant influence on stand density $(r=-0.07)$, basal area $(r=0.02)$, or percent of pine killed $(r=0.14)$. Mean pine site index for plots within the area of contiguous heavy tree mortality was 52.4, significantly higher $(P=0.01)$ than the 46.0 for plots within the same elevation range where beetle-caused tree mortality was less. Site index did not change with elevation or aspect.

The density of ponderosa pine trees was significantly less $(P<0.05)$ on south and east slopes than on the west aspect (table 5). But percent of trees killed by beetles was not different between aspects.

\section{Douglas-fir}

Thirty-one plots on north-facing slopes were analyzed for the influence of the Douglas-fir component on ponderosa pine mortality caused by beetles. Douglasfir ranged from $0 \%$ to $94 \%$ of all trees, averaging $37 \pm 14 \%$. No relationship was detected in a comparison of the number of Douglas-fir trees per acre with the percent of ponderosa pines killed by the mountain pine beetle, or of Douglas-fir stems, as a percent of all stems, with the percent of ponderosa pine killed by beetles. The Douglas-fir component appears to have increased following the beetle outbreak, but the difference is not statistically significant (table 5).

Amman and Baker (1972) reported that mixed stands of up to $36 \%$ trees of other species (other than lodgepole pine (Pinus contorta Dougl.)) were as susceptible to mountain pine beetles as those with less than $10 \%$ of other species. McGregor (1978) also reported similar results in lodgepole pine.

The data indicate that efforts to reduce pine mortality during beetle outbreaks by increasing the amount of Douglas-fir in the stand will not be effective unless something approaching a complete type conversion is effected.

\section{Dwarf Mistletoe}

The relationship between ponderosa pine dwarf mistletoe and increased susceptibility to mountain pine beetle has long been a subject of speculation. Various reports from the Colorado Front Range suggest that stands heavily infested by dwarf mistletoe are more 
susceptible to the beetle (Cahill 1975, Creasap 1977, Frye and Landis 1975, Johnson et al. 1976). In the most detailed study (Johnson et al. 1976), four areas totaling 86 acres were examined in the Pike-San Isabel $\mathrm{Na}$ tional Forest (three stands) and in the ArapahoRoosevelt National Forest. In areas where dwarf mistletoe infestation was low (stand mistletoe ratings of 0.3 to 0.9 ), there was no relationship between dwarf mistletoe and mountain pine beetle attack. Only when dwarf mistletoe rating of the stand averaged 1.4 was there a significant trend for mountain pine beetles to infest mistletoe-infected trees.

In this study, dwarf mistletoe was found in 41 of the 179 forested plots $(23 \%)$. There was a definite increase of dwarf mistletoe with elevation. No infection was found in plots under 6,000 feet, but $45 \%$ of the plots in the highest parts of the area (over 6,800 feet) had mistletoe.

For the 41 plots with mistletoe, $52.9 \%$ of the trees were infected; however, only an average of $12.1 \%$ of the trees were infected in the entire area. A greater percentage of dwarf-mistletoe-infected ponderosa pines was killed by mountain pine beetle (30.8\%) than of uninfested trees $(20.5 \%)$. This trend was fairly consistent in each diameter class (table 6), but the data for trees over 13 inches d.b.h. are scanty.

A stand summary of dwarf-mistletoe-infested versus uninfested plots (table 7) shows beetle-caused losses, as measured by percent of stems killed, basal area, merchantable cubic foot volume, and board foot volume, were significantly higher $(P<0.1$ by $t$ test $)$ in mistletoe-infested plots. The differences in proportion of trees killed in dwarf-mistletoe-free plots $(16 \%)$ versus that in infested plots (39\%) is greater than for uninfected versus infected trees (table 6, 20\% versus $31 \%)$. We interpret this to mean that not only are dwarf-mistletoe-infected trees more susceptible to the beetles, but adjacent, nondiseased trees are also more susceptible because of the attractive odors released by female beetles attacking the diseased trees.

The incidence of dwarf mistletoe was not influenced by number of trees per acre or tree size.
Table 6.- Relationship between mountain pine beetle kill, dwarf mistletoe infection and diameter class

\begin{tabular}{|c|c|c|c|c|}
\hline \multirow{2}{*}{$\begin{array}{l}\text { Diameter } \\
\text { class - } \\
\text { midpoint }\end{array}$} & \multicolumn{2}{|c|}{$\begin{array}{c}\text { Mistletoe-infected } \\
\text { trees per acre }\end{array}$} & \multicolumn{2}{|c|}{$\begin{array}{l}\text { Mistletoe-free } \\
\text { trees per acre } \\
\end{array}$} \\
\hline & Total & Killed & Total & Killed \\
\hline inches & number & percent & number & percent \\
\hline 11 & 2.9 & 0 & 57.7 & 13.4 \\
\hline 3 & 15.8 & 10.6 & 89.3 & 6.8 \\
\hline 5 & 9.5 & 25.8 & 62.6 & 16.3 \\
\hline 7 & 7.2 & 56.3 & 42.3 & 33.1 \\
\hline 9 & 3.9 & 66.7 & 31.2 & 40.3 \\
\hline 11 & 2.6 & 46.2 & 19.0 & 42.7 \\
\hline 13 & 2.4 & 66.7 & 11.7 & 39.4 \\
\hline 15 & 0.8 & 50.0 & 6.3 & 40.6 \\
\hline 17 & 0.3 & 33.3 & 2.5 & 32.0 \\
\hline 19 & 0 & 0 & 1.0 & 20.0 \\
\hline 21 & 0 & 0 & 0.3 & 33.3 \\
\hline Total & 45.4 & 30.8 & 323.9 & 20.5 \\
\hline
\end{tabular}

10-1.9, etc.

Dwarf mistletoe was most abundant in the 163-acre area of heavy beetle damage $(8$ of 17 plots, compared to 33 of 162 plots in the rest of the area).

Dwarf mistletoe in the original stand, in trees $\geqslant 6$ inches d.b.h., was found overwhelmingly on west aspects, where $48.7 \%$ of the stems were infected. Pines on south aspects had an $8.4 \%$ infection; east, $7.9 \%$, while $2.1 \%$ on north aspects were infected. Such large differences have not been rècorded in other studies for this mistletoe in the southwest (Hawksworth 1959, Andrews and Daniels 1960).

\section{Summary}

An uncontrolled mountain pine beetle outbreak ran its course during a 14-year period in the ponderosa pine forest of Lory State Park, 7 miles west of Fort Collins, Colo. These findings are generalizable to the ex-

Table 5.-Aspect, site class, and Douglas-fir component as related to mountain pine beetle impact on ponderosa pine

\begin{tabular}{|c|c|c|c|c|c|c|c|c|}
\hline \multirow[b]{3}{*}{ Aspect ${ }^{1}$} & \multirow{3}{*}{$\begin{array}{c}\text { Number } \\
\text { of } \\
\text { plots }^{2}\end{array}$} & \multicolumn{2}{|c|}{ Site index } & \multirow{3}{*}{$\begin{array}{c}\text { Original } \\
\text { ponderosa } \\
\text { pine stems } \\
\text { per acre }\end{array}$} & \multirow{3}{*}{$\begin{array}{c}\text { Ponderosa } \\
\text { pine } \\
\text { mortality }\end{array}$} & \multirow{2}{*}{\multicolumn{3}{|c|}{ Douglas-fir stems ${ }^{3}$}} \\
\hline & & \multirow{2}{*}{$\begin{array}{l}\text { Ponderosa } \\
\text { pine }\end{array}$} & \multirow{2}{*}{$\begin{array}{l}\text { Douglas. } \\
\text { fir }\end{array}$} & & & & & \\
\hline & & & & & & Original & Post.outbreak & Differences $^{3}$ \\
\hline & & & & & & & percent & \\
\hline North & 31 & 46 & 64 & 452 & 26.2 & 37.5 & 44.4 & NS \\
\hline East & 22 & 50 & 60 & 161 & 27.6 & 21.6 & 27.6 & NS \\
\hline South & 17 & 45 & -- & 155 & 18.0 & 1 & 1 & \\
\hline West & 8 & 46 & - & 730 & 23.1 & 1 & 1 & \\
\hline
\end{tabular}

'Cardinal directions $\pm 20^{\circ}$.

${ }^{2}$ Plots on level ground, or those on aspects other than the cardinal directions are not represented. Hence the total of 78 plots out of 179.

${ }^{3}$ Significance of differences between North and East determined by $t$ test with arcsin transformation. 
Table 7.-Comparision of ponderosa pine in plots with and without dwarf mistletoe, after mountain pine beetle attack

\begin{tabular}{|c|c|c|c|c|c|}
\hline \multirow[b]{2}{*}{$\begin{array}{l}\text { Stand } \\
\text { condition }\end{array}$} & \multirow[b]{2}{*}{$\begin{array}{l}\text { number } \\
\text { of plots }\end{array}$} & \multicolumn{4}{|c|}{$\begin{array}{l}\text { Percent loss to mountain } \\
\text { pine beetle }\end{array}$} \\
\hline & & $\begin{array}{l}\text { Number } \\
\text { of stems }\end{array}$ & $\begin{array}{c}\text { Basal } \\
\text { area }\end{array}$ & $\begin{array}{l}\text { Merchantable } \\
\text { cubic feet }\end{array}$ & $\begin{array}{c}\text { Board } \\
\text { feet }\end{array}$ \\
\hline $\begin{array}{l}\text { Mistletoe-free } \\
\text { With mistletoe } \\
\text { Significance level }\end{array}$ & $\begin{array}{r}138 \\
41\end{array}$ & $\begin{array}{r}16 \pm 1 \\
39 \pm 5 \\
0.01\end{array}$ & $\begin{array}{r}28 \pm 3 \\
46 \pm 5 \\
0.01\end{array}$ & $\begin{array}{r}32 \pm 3 \\
50 \pm 5 \\
0.01\end{array}$ & $\begin{array}{r}33 \pm 3 \\
53 \pm 6 \\
0.01\end{array}$ \\
\hline
\end{tabular}

tent the situation described might be considered a microcosm of the ponderosa pine type of the Roosevelt National Forest and adjacent private lands.

The mountain pine beetle killed $25 \%$ of the ponderosa pine trees 4.5 feet and taller, or 92 trees per acre, over the entire 1,220 forested acres in the park. Merchantable wood volume loss was about 960 board feet per acre.

Much heavier tree mortality occurred in scattered locations. In one area of 163 acres, $49 \%$ of all ponderosa pine trees taller than 4.5 feet were killed by beetles. This represented a loss of about 3,000 board feet $(99 \%)$ of the merchantable volume per acre. Basal area and site index were significantly higher in the area of highest tree mortality, but mean tree diameter was lower. Density of trees looked considerably higher but failed to be statistically different from the other areas. This variable should be studied further before the statistical evidence is accepted. A high proportion of tree loss in the area of heavy, contiguous, beetlecaused tree mortality was on the leeward side of ridges. This facet of beetle-host relationship also warrants further study.

Percent of pines killed increased steadily with tree diameter up to about 9 inches. Beyond that diameter, tree mortality remained high but appeared random, especially in the largest diameter classes. All trees in some diameter classes were killed, but some big trees survived. However, mean tree diameter was lowered as a result of the beetle outbreak.

There was no tree diameter evident below which ponderosa pine is immune from beetle attack during an outbreak.

The original density of ponderosa pine correlated fairly well with trees killed by beetles, $r=0.71$, but not with percent of pine killed, $r=-0.001$. Interaction of tree density with tree diameter did not materially strengthen the correlation. Original basal area of pine was less well correlated with pine trees killed, $\mathrm{r}=0.61$. The correlation with percent of trees killed was $r=0.15$.

Elevation, site index, aspect, or amount of Douglasfir mixture with pine had no measurable influence on the amount of pine mortality caused by mountain pine beetles in this outbreak.
A greater percent of dwarf-mistletoe-infected trees was killed than those free of infection. Infection was fairly uniform between diameter classes. However, greatest percent of beetle-caused mortality occurred in trees from 12 to 13.9 inches d.b.h. This may be more diameter-related than due to dwarf mistletoe. Influence of the intensity of infection and beetle susceptibility could not be determined by this study. Adequate numbers of dwarf-mistletoe-infected trees of all diameters remain in the residual stand to maintain the disease.

The magnitude of mountain-pine-beetle-caused forest destruction reported here may help one more realistically evaluate the need for direct chemical control programs. Certainly all trees are not destroyed. A program of stand thinning, coupled with use of the highly effective and economical protective sprays of carbaryl (McCambridge 1981), supplemented by judicious direct control as outlined by Stevens et al. (1975), would enable private landowners to do much to limit tree losses, even during epidemic periods.

\section{Literature Cited}

Amman, Gene D., and Bruce H. Baker. 1972. Mountain pine beetle influence on lodgepole pine stand structure. Journal of Forestry 70:204-209.

Andrews, Stuart R., and John P. Daniels. 1960. A survey of dwarfmistletoes in Arizona and New Mexico. Station Paper 49, 17 p. U.S. Department of Agriculture, Forest Service, Rocky Mountain Forest and Range Experiment Station, Fort Collins, Colo.

Cahill, Donn B. 1975. Mountain pine beetle, Colorado Front Range. Arapaho-Roosevelt, Pike-San Isabel National Forests, and Rocky Mountain National Park. USDA Forest Service, Rocky Mountain Region, Forest Insect and Disease Biological Evaluation R-2-75-22, 4 p. Lakewood, Colo.

Cole, Walter E., and Gene D. Amman. 1969. Mountain pine beetle infestations in relation to lodgepole pine diameters. USDA Forest Service Research Note INT-95, 7 p. Intermountain Forest and Range Experiment Station, Ogden, Utah. 
Creasap, Vernon L. M. 1977. Mountain pine beetle. National forest lands. Colorado Front Range. ArapahoRoosevelt, Pike and San Isabel National Forests. USDA Forest Service Rocky Mountain Region, Forest Insect and Disease Biological Evaluation R-2-77-4, 7 p. Lakewood, Colo.

Frye, Robert H., and Thomas D. Landis. 1975. Mountain pine beetle and dwarf mistletoe, Lake Creek Area, San Carlos Ranger District, Pike-San Isabel National Forest, USDA Forest Service, Rocky Mountain Region, Forest Insect and Disease Biological Evaluation R-2-75-4. 10 p. Lakewood, Colo.

Hawksworth, Frank G. 1959. Distribution of dwarfmistletoes in relation to topography on the Mescalero Apache Reservation, New Mexico. Journal of Forestry 57:919-922.

Hawksworth, Frank G. 1977. The 6-class dwarf mistletoe rating system. USDA Forest Service General Technical Report RM-48, 7 p. Rocky Mountain Forest and Range Experiment Station, Fort Collins, Colo.
Johnson, D. W., L. C. Yarger, C. D. Minnemeyer, and V. E. Pace. 1976. Dwarf mistletoe as a predisposing factor for mountain pine beetle attack of ponderosa pine in the Colorado Front Range. USDA Forest Service, Rocky Mountain Region, Forest Insect and Disease Technical Report R-2-4, 7 p. Lakewoood, Colo.

McCambridge, W. F. 1982. Field tests of insecticides to protect ponderosa pine from the mountain pine beetle. Journal of Economic Entomology. (In press).

McGregor, Mark D. 1978. Management of mountain pine beetle in lodgepole pine stands in the Rocky Mountain area. p. 129-139. In Proceedings of the symposium: Theory and practice of mountain pine beetle management in lodgepole pine forests. [Washington State University, Pullman. April 25-27, 1978].

Meyer, Walter H. 1938. Yield of even-aged stands of ponderosa pine. USDA Technical Bulletin No. 630, 59 p. Washington, D.C.

Stevens, Robert E., Clifford A. Myers, William F. McCambridge, George L. Downing, and John G. Laut. 1975. Mountain pine beetle in Front Range ponderosa pine. USDA Forest Service General Technical Report RM-7, 3 p. Rocky Mountain Forest and Range Experiment Station, Fort Collins, Colo.

\section{Acknowledgments}

The authors thank Morris Brown and Robert Morris of the Colorado Division of Parks and Outdoor Recreation for making the area available for study. We thank the Colorado State Forest Service for 77 worker-days of field work contributed to the study. 



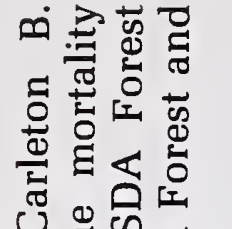

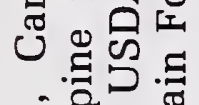

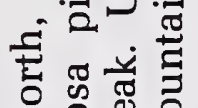

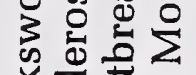

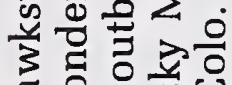

空造记

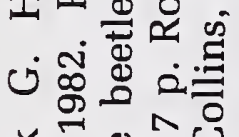

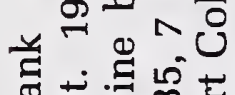

ฮี่

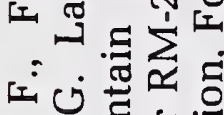

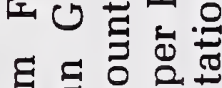

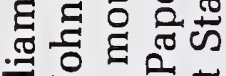

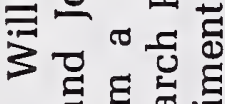

ธี छี

品

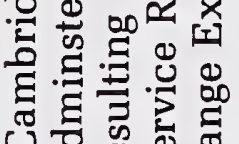

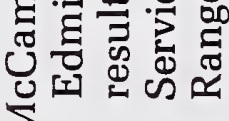

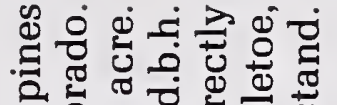

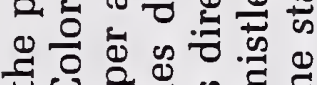

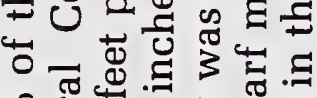

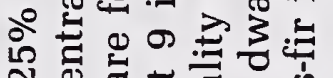

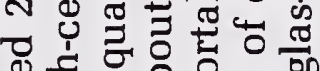

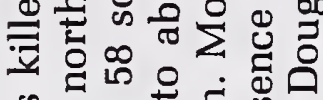

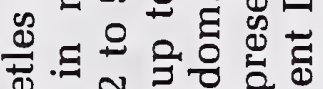

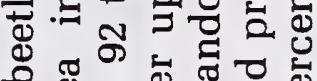

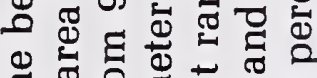

๘

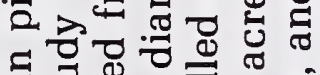

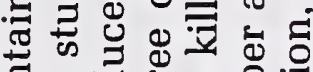

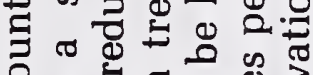

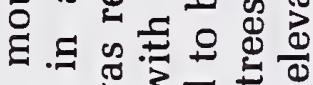

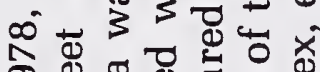

Oิ

ㄴ 1 เ

น +

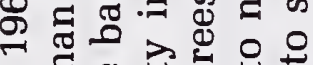

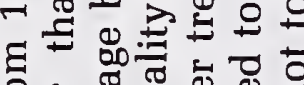

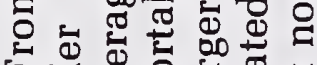

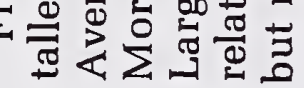

๓

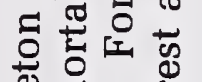

क्ष

Ðึ

的.

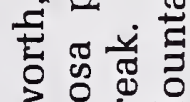

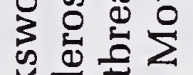

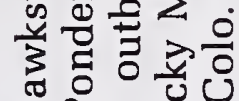

西口包

৩ ปิ

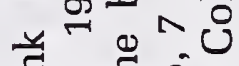

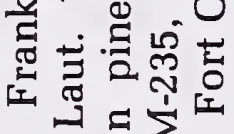

计劳专

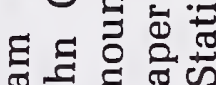

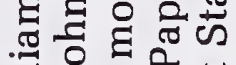

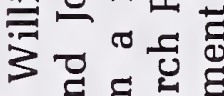

๘

离

D象

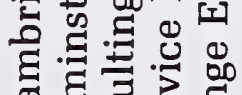

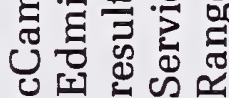

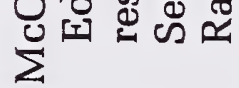

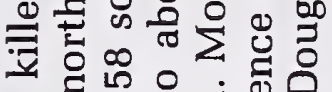

ة

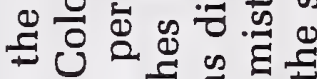

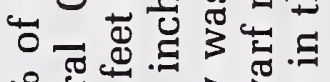

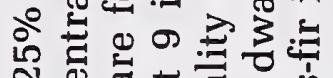

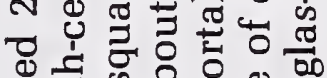

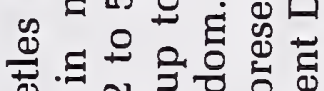

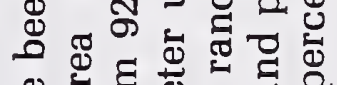

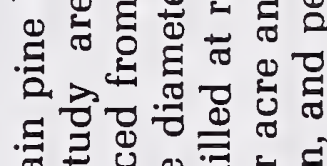

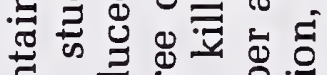

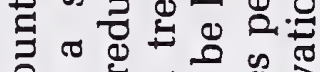
․․

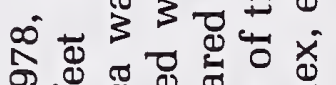

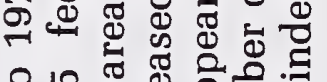
ㄴำ

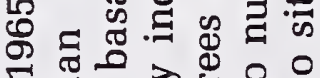

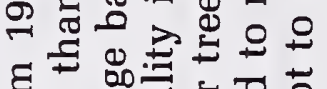
대월

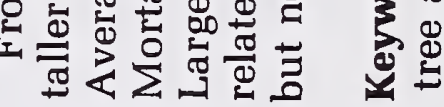

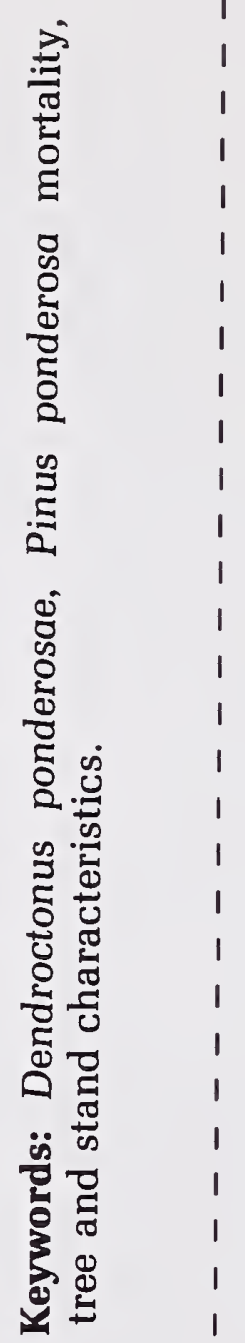

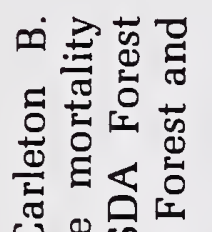
ن 罗. 进范

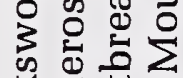

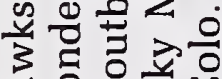
空。

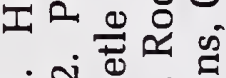
ن है

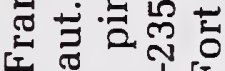
$\therefore$ 等

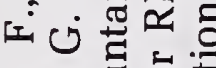

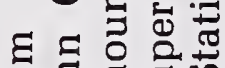
을응 उす

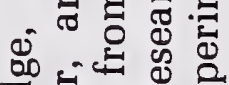

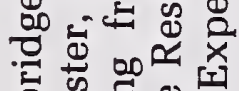
है. हี ن्ट

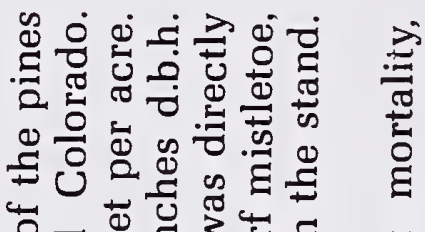

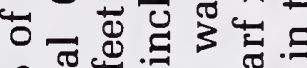

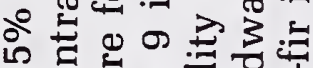

윰

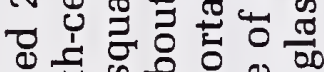

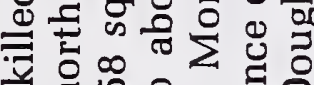

ซ

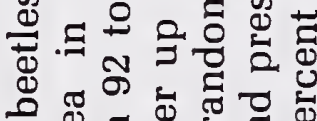

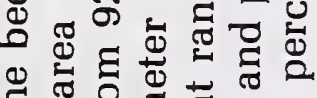

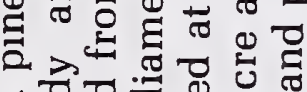

궁혀웜

कृ

苛

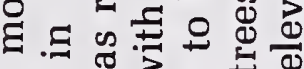

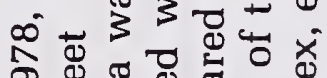

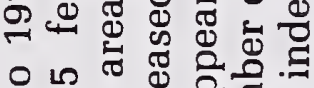

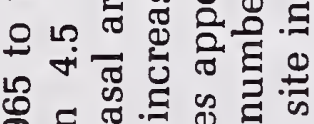

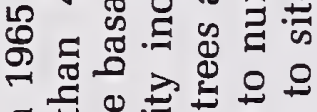

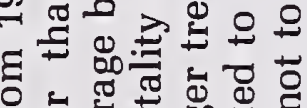

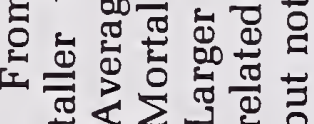

$\infty \geq$

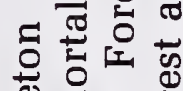

인

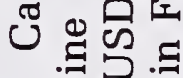

ำ

壱范菏

3 윤

굴 홍응

空웡

证

ن

है

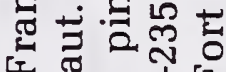

四我

地讨元众

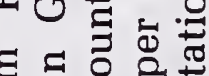

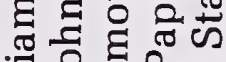

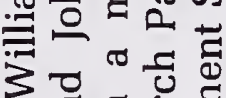

उ $\varepsilon$

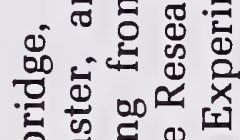

है क्ञ.

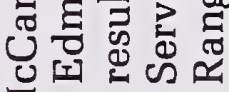

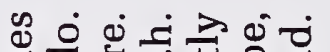

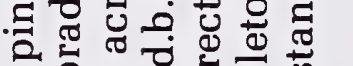
응 牙焉 क U

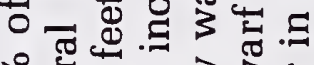

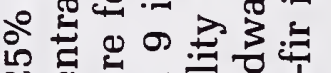
월

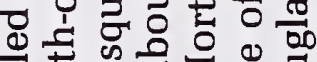

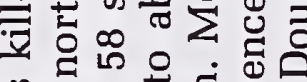

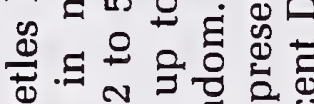

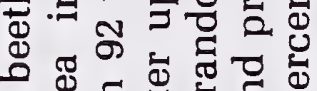

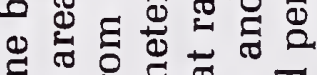

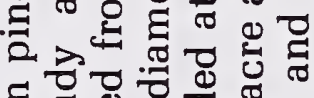

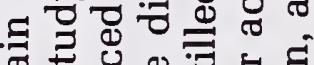

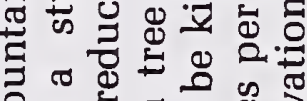

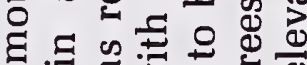

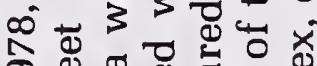

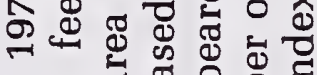
ㅇ

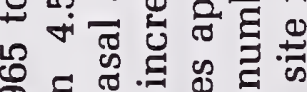

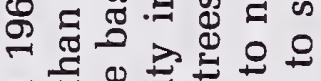

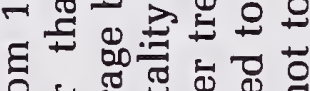

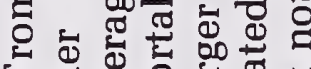

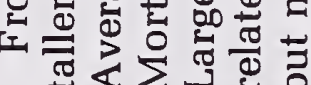

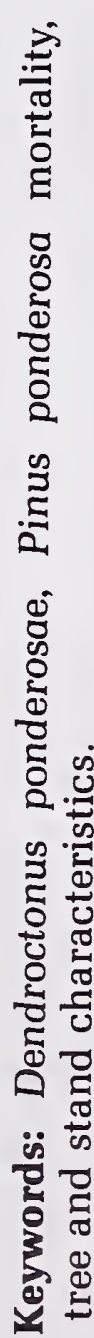



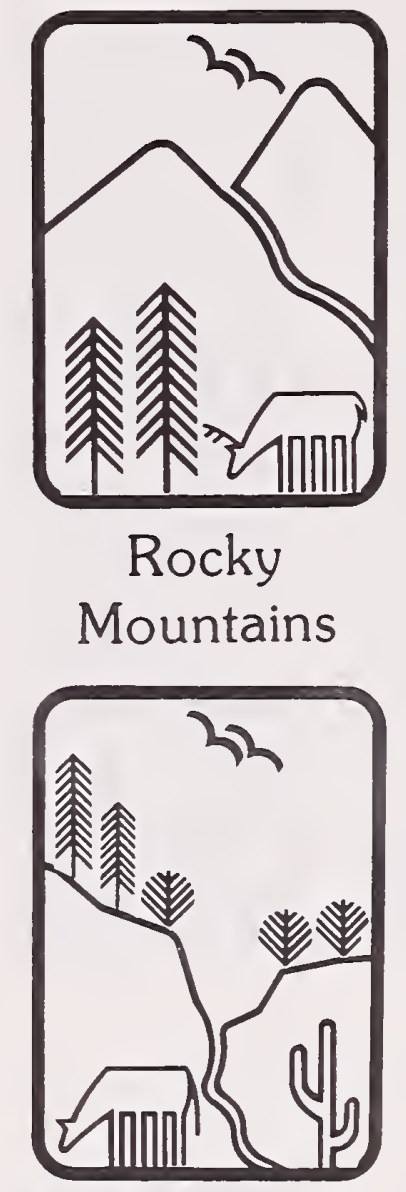

Southwest

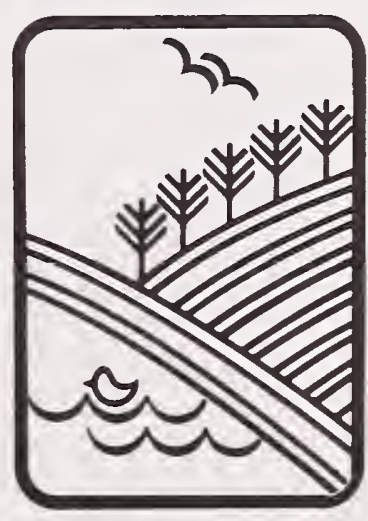

Great

Plains
U.S. Department of Agriculture Forest Service

\section{Rocky Mountain Forest and Range Experiment Station}

The Rocky Mountain Station is one of eight regional experiment stations, plus the Forest Products Laboratory and the Washington Office Staff, that make up the Forest Service research organization.

\section{RESEARCH FOCUS}

Research programs at the Rocky Mountain Station are coordinated with area universities and with other institutions. Many studies are conducted on a cooperative basis to accelerate solutions to problems involving range, water, wildlife and fish habitat, human and community development, timber, recreation, protection, and multiresource evaluation.

\section{RESEARCH LOCATIONS}

Research Work Units of the Rocky Mountain Station are operated in cooperation with universities in the following cities:
Albuquerque, New Mexico
Bottineau, North Dakota
Flagstaff, Arizona
Fort Collins, Colorado*
Laramie, Wyoming
Lincoln, Nebraska
Lubbock, Texas
Rapid City, South Dakota
Tempe, Arizona

"Station Headquarters: 240 W. Prospect St., Fort Collins, CO 80526 